\begin{tabular}{|c|}
\hline $\begin{array}{c}\text { ASIAN SOCIAL WORK } \\
\text { JOURAL } \\
\text { (ASW) }\end{array}$ \\
Volume 2, Issue 1, September 2017 \\
Journal home page: \\
www.msocialwork.com \\
\hline
\end{tabular}

\title{
Role of Social Workers in Facilitating of the Poverty Alleviation Program in Indonesia
}

\author{
Anwar Sitepu ${ }^{1}$ \\ 1The Center for Research and Development of Social Welfare, \\ Social Ministry of the Republic Indonesia \\ Corrrespondence: Anwar Sitepu (sitepu.anwar@yahoo.co.id)
}

\begin{abstract}
This paper aims to describe the idea of the professionalization of handling the poor in Indonesia, namely through the establishment of a social worker assistant the poor. Poor Social Worker Companion who is a professional social worker was appointed assistant the poor. Professionalization companion deemed urgent. The poor handling challenge because it is more difficult. The fact is: 1) the number of poor people in Indonesia is still high; 2) the pace of decline slowed down the number of poor people; 3) There are a large number of residents are not poor are vulnerable to fall back into poverty. On the other hand, the poor management program through its joint (Kube) has not been effective enough. Recent research shows that only 40 percent Kube established in 2013 is still active when checked 30 months later. This finding is in line with the results of evaluations conducted since decades ago. This condition is alarming and needs improving the poor handling system significantly. One of the components is seen as strategic human resources. Suggested remedies are by appointment professional social workers to become a partner. The social worker assigned duties and functions facilitate the handling of the poor in a certain area within a certain time. The function of the social worker suggested the poor companion is: a) guide the community to collect data on available data the poor by name by address in its territory; b) verification and validation of data the poor; c) selecting program participants the poor handling; d) perform reference handling the poor; e) advocate for the Poor that all rights are met; f) The poor family counseling; g) make public the guidance in the handling of the Poor; h) monitoring and evaluating the progress of the Poor; i) make the case record the poor family; and h) report on the implementation of tasks. The social worker is deemed appropriate to perform this task because they are trained to help people meet their mission needs, support, knowledge, values, and skills.
\end{abstract}

Key words: social workers, counselors, family, poverty

\section{Introduction}

The number of Indonesians living in poverty is still quite high, covering 28.59 million people or 11.22 percent of the total population in March 2015 (Badan Pusat Statistik, 2017). Indeed this number is already an achievement because formerly the amount is much higher (Anwar Sitepu, 2016). About twenty years ago, 1997-1998, when the economic crisis broke out and later developed into a multidimensional crisis the number of poor people included 49.5 million people or 24.2 percent of the 
population. However, the welfare of the population can be improved gradually, many poor people release from poverty, thus the number of poor people is reduced to the position.

As Indonesian independence stated, poverty must be overcome. In the opening of the Constitution of the Unitary State of the Republic of Indonesia (UUD) in 1945 declared expressly to promote the general welfare, educate the life of the nation. Then inside the trunk is specifically mentioned that poor people and neglected children are taken care by the state. The whole nation-building effort can actually be understood as an effort to improve the general welfare, including overcoming the problem of poverty.

\section{Poverty Alleviation Program in Indonesia}

In an effort to intensify the improvement of the welfare of the population, since the 1990s the government has organized special programs focusing on poverty alleviation. In 1993, the Government issued Presidential Instruction (Inpres) No. 3 of 1993, which became the basis for the implementation of the Poverty Reduction Program. Then became the Prosperous Family Development program in the context of Improving Poverty Reduction (Inpres RI No 3 of 1996) and popularly called "Strengthen Program Eradicate Poverty (MPMK). Since the multidimensional crisis of 1997/1998, the government has organized programs aimed directly at poverty alleviation, including: the Urban Poverty Prevention Project (popularly called P2KP), 1997; Social Safety Net (JPS); Food Security Loan Program (KKP); Direct Cash Transfer (BLT) as compensation for the fuel price hike (until 2006); Family Hope Program (since 2007); National Program for Independent Community Empowerment (PNPM).

In 2010, poverty alleviation programs were organized more systematically, through Presidential Regulation No. 10/2010 on the Acceleration of Poverty Reduction. Through the Presidential Regulation, it is mandated to organize 4 groups of poverty reduction acceleration programs and the establishment of the National Team for the Acceleration of Poverty Reduction (TNP2K). The four groups of programs are:

1. A family-based integrated family assistance program group, aimed at fulfilling basic rights, reducing the burden of life, and improving life quality of the poor;

2. The community empowerment-driven poverty program group aims to develop the potential and strengthen the capacity of the poor to engage in development based on community empowerment principles;

3. Group of poverty reduction programs based on empowerment of micro and small business enterprises, aims to provide economic access and strengthening for micro and small scale business actors;

4. Other programs that either directly or indirectly can improve the economic activities and welfare of the poor.

One of the results of this Presidential Regulation is the formation of Integrated Database (BDT) of the poor.

In the current government, 2014-2019, poverty alleviation in Indonesia is conducted through the Poverty Reduction Program which is regulated in Presidential Decree Number 166 of 2014. This program includes a number of social protection programs, namely: 1) Prosperous Family Deposit Program (with KKS); 2) Healthy Indonesia Program (with KIS); and 3) Smart Indonesia Program (with KIP). The current government sets a target of reducing the number of poor to around 8 percent by 2019.

The problem faced in recent years in the implementation of poverty reduction programs (in common sense) is that: 
Increasingly difficult to reduce the poor. The data of the poor in Indonesia in recent years indicate that the reduction of the number of poor people tends to slow down. In the past 10 years, 2007-2016, the decline of the poor fell from 16.58 in 2007 to 10,86 percent by 2016, or covering 5.72 percent. Or an average of 0.57 percent per year. Absolute down from 37.17 million people in 2007 to 28.01 million people in 2016, or reduced by 9.16 million people in 10 years. In the last five years of 2012 to 2016, downward trend slowed down from 11.66 to 10.86 percent. This means that for 5 years reduced by 0.8 percent, an average of 0.16 percent per year, smaller than the period 2007 to 2011 , from 16.58 to 12.36 , 4.22 percent or an average of 0.84 percent per year. The decline in the number of poor people is influenced by many factors, especially by economic turmoil. (https://www.bps.go.id/linkTableStatis/view/id/1494, accessed on July 12, 2017)

The vulnerable population in and out of poverty. The data shows that the number of poor people has ups and downs. At the beginning of the five-year development, the number/percentage of poor people reached 40.01 percent (in 1976). Within 20 years, it dropped to 11.7 percent in 1996. But in 1997 it increased again to 17.7 percent and in 1998 to 24.2 percent. Since 1998 until now 2016 has gradually decreased but often fluctuated. In the downward trend, the surge occurred in 2006 to 17.75 from 15.97 in the previous year, 2005. The smaller percentage of poor people on a smaller scale again occurred in 2013 in March 11.37 to 11.47 in September. In absolute numbers from 28.01 million people to 28.55 million people. That is, there are as many as 540,000 people who in March were not poor to poor in September (https://www.bps.go.id/link TabelStatis /view/id/1494 accessed on July 12, 2017). Overall, the rise and fall of the percentage of poor people imply that there are vulnerable groups of people falling back below the poverty line. The conditions of vulnerability need to be given attention. They cannot be considered "safe". Without protection, this vulnerable population group may fall back on time. Furthermore, if the poverty line margin is slightly shifted higher than the number/percentage of the poor will immediately jump.

Referring to the data problem, although a big step in the case of data has been done, that is by bringing together data in so-called integrated database (BDT) which is managed by National Team for Acceleration of Poverty Reduction (TNP2K), however, it has not solved the problem yet. Until now there are still problems, there are some people who feel poor but have not registered in BDT (exclusion error). On the other hand, there are families that are not poor but registered in BDT and become beneficiaries of social protection programs (inclusion error). The implication is that those who are entitled to social protection do not get, on the contrary, those who are not worthy, have social protection. This is related to eligibility and justice. Those who feel entitled but have not received protection feel treated unfairly.

Meanwhile, according to the National Development Planning Agency (Bappenas) (2009), the main problem faced by Indonesia in reducing the number of poor people among others is: First, the development efforts undertaken are still uneven and have not reached all levels of society, especially in rural and outside Java. Second, the implementation of the development program is still partial and not yet focused. Third, the community's independence in the community-based development process is still very limited.

Then, according to the National Team for the Acceleration of Poverty Alleviation (TNP2K) (2016), the obstacles faced in poverty alleviation are Development concept aimed at reducing poverty generally through the top-down mechanism. The weakness of this mechanism is without the participation of the community. All poverty reduction program initiatives come from the (central) government, as well as the handling. Implementation guidance and technical guidance of program implementation are always made uniformly regardless of the characteristics of the poor in each region. As a result, the programs provided often have no correlation with the priorities and needs of the local poor. With these considerations, thorough efforts accompanied by the empowerment of the poor become one of the key principles in poverty reduction strategies (TNP2K, 2016).

Ministry of Social Affairs is one of the ministries that organizes poverty alleviation program. Ministry of Social Affairs even since the beginning of the establishment after the proclamation of 1945 already takes care of poor people. In fact, all the activities of the Ministry of Social Affairs can be categorized 
as an effort to handle the poor, whether social rehabilitation, social protection, and security, social empowerment can be fully understood or categorized as the handling of the poor. In addition to these three areas of the social department has its own special program for handling poor people. Poor people handling activities are even strengthened through the stipulation of RI Law No.13 / 2011 and the establishment of a special work unit, at Echelon I level.

Poor people handling by Ministry of Social Affairs are done through a group of joint ventures, abbreviated Kube. This model has been used for 33 years, since 1984. The components of the poor people handling program by the Ministry of Social Affairs are social assistance of business capital (also called stimulant), mentoring, skill development, social assistance for environmental improvement (popularly called sailing), social assistance for house rehabilitation uninhabitable popular called rutile). In its implementation, each runs on its own.

The problem faced by the Social department is a strong indication that KUBE has not been effective enough (Sitepu, 2016). The indication is expressed by a number of evaluation results conducted by various parties in a relatively long period of time. The latest results of the 2016 Puslitbang Research conducted in 8 cities (Binjai, Medan, Bandung, Bogor, Bekasi, Banjarmasin, Tomohon and Manado) showed that from 331 KUBE established in 2013, the active ones include 134 or 40.01 Percent (Pusat Penelitian dan Pengembangan kesejahteraan Sosial,2017). However, this figure is not good enough for two reasons: first, the quantity is relatively small, more inactive; Second, in quality, judging by the number of active members and the frequency of business transactions. Active KUBE limitation is to conduct business transactions at least 1 time in the last 6 months. The number of members involved at least 3 people. Of the 134 active KUBE majorities are active in the minimal sense, the frequency of low transactions and the members involved less than 10 people. Overall this means or shows that the KUBE condition is still not as expected, has not been able to realize the mission, increase family income. KUBE performance is not maximized due to 5 interrelated factors, namely: 1) the implementation process of KUBE formation activities has not done well; 2) there are no technical guidelines for the implementation of activities; 3) the quality of human resources for program programming and program beneficiaries is not sufficient (commitment and knowledge); 4) Control of activities has not been effective; 5) KUBE concept has not accommodated member aspirations. Overall the core of the problem is that poor people handling has not been done intensively tend to be simple. The findings of this study are in line with the evaluation conducted by other parties between 2003 and 2015 (Anwar Sitepu, 2016).

Such conditions need to be addressed immediately. Looking at the above description, the required poor people handling efforts are those that have the following characteristics: 1) able to reduce the mass of the poor massively; 2) able to maintain the continuous improvement of the welfare of poor families; 3 ) able to integrate/synchronize/synergize various poor people handling programs; 4) involve the active participation of the community in a series of processes, from data collection to implementation and evaluation of activities; 5) able to develop the power of local communities to grow independently. Therefore it is deemed necessary to rearrange poor people handling the program. One of the components that need to be laid out is human resources (HR). In RI Law No.13 / 2011 stated that the human resources management of poor people handling includes: social welfare workers, social professional workers, social instructors, volunteers, and companions. So far the four human resources have not been clearly defined, but in the operational program in the field, the human resources used as the spearhead is a companion. The companion is considered to have a strategic position because it directly serves clients in the field.

\section{Issues of Poor People}

Poor people is a person who has no source of livelihood and/or has a source of livelihood but does not have the ability to fulfill basic needs appropriate for his / her life and/or family (The Republic of Indonesia, 2013). According to this understanding, it can be understood that a person or a family categorized as poor people lives in conditions that are both alarming and even critical. This happens because the basic needs, according to poor people indicators (Social Department, 2013), such as food, 
clothing, and shelter, including the need for clean water and lighting are not met well. The sick person is only able to seek treatment at the health center or other facilities subsidized by the government. In other words, if any member requires further treatment outside of the services provided by the Public Health then the family is unable to access it unless there is a subsidy. That is, if one of the family members suffer from illness then it will not be treated in medical facilities, may be taken home and seek alternative treatment, such as a shaman or treated potluck. Whereas on the other hand, the physical condition of poor people family is very vulnerable because the fulfillment of their basic food needs is not fulfilled. Their residence is also less comfortable because roofs, floors, and walls of dwellings are all in bad condition. Drinking water sources are also quite vulnerable, in the form of wells or river water or rainwater, which are all relatively unhygienic. Usually, they are housed in poor neighborhoods or even completely unhealthy, dense, shabby, environmental facilities such as sewerage sewers, and others.

Furthermore, such living conditions are unclear endpoints, meaning they will continue throughout life and are likely to be passed on to the next generation. In poor people families, children are the most vulnerable, they are in a period of growth but do not get enough intake. Even in the womb the babies already bear the impact of poverty, so they are born in size (length and weight) below the standard. The percentage of Indonesian children with short-term body length $(<48 \mathrm{~cm})$ and short $(48-52 \mathrm{~cm})$ is still quite high, at 20.2 percent and 76.4 percent (Riskesdas, 2013). At school age, they also can not access higher education level than the First Level Advanced School. Under such conditions, it can be understood that it would be very difficult for a person or poor people family to work (out) for the poor, without any help from others.

So far there has been no official data on how many poor people in Indonesia. The available data are 1) the data of the poor determined by the amount of income; and 2) relative poor data. The data of the poor are people who have income below the poverty line (GK). According to poverty, BPS groups people into 3 groups: poor, near poor and very poor. Very poor people are people who earn about 60 percent under the GK. The near-poor are those who earn 1.25 times the GK. The Poverty Line is a representation of the minimum amount of rupiah required to meet the minimum basic needs of food equivalent to 2100 kilocalories per capita per day and non-food basic needs. So far there has been no formal agreement called poor people like what or where the income limit to separate someone is categorized as poor people. However, the trend is that at least administratively poor people is the poorest inhabitants. This means covering people with incomes lower than GK. It should also be noted that the GK is set differently by region, currently, the National GK is Rp.356.000, -

There are many views about poverty. A view that is popular recently is the view of Amartya Sen. According to Amartya Sen (1999) the core of poverty is not merely low income, but rather a matter of capability deprivation or a loss of capacity to get out of the structural poverty shackles. Such understanding may help explain the two phenomena above, namely the slowdown in the decline in the number of poor and vulnerable non-poor to return to fall into poverty. Referring to Amartya Sen's opinion, the capacity of the poor may indeed be considerably less. The capacities in question include power, opportunity and security and social security that are interconnected with each other. Capability Deprivation traps the poor into poverty. Such a view is more likely to see deficiencies in the poor. In the conception of social work, the poor is a troubled person who needs help. Referring to the concept of social functioning (Suharto, Edi, 2016), the poor people family is in a dysfunctional situation. Social work understands the poor people problem in terms of the environment, human-in-environment. Problems are not solely on the shortcomings of people, such as Sen's thoughts above. Departing from that view, social intervention is aimed at people as well as in the environment at once, so as to achieve a balanced relationship, where people can (have the capacity to) obtain the needs of their environment. On the other side of the environment is responsive to its citizens.

\section{Poor People in Alleviation of Their Poor}

The handling of poor people in Indonesia is regulated in RI Law Number 13 The year 2011. In the Act stated that the handling of the poor is a directed, integrated, and sustainable effort by the Government, 
local government and/or the community in the form of policies, programs And empowerment, facilitation, and facilitation activities to meet the basic needs of every citizen (ps 1). Meanwhile, basic needs are food, clothing, housing, health, education, employment, and/or social services. Departing from these provisions it becomes clear that the expected poor people handling are done directed, integrated and sustainable to meet the basic needs of every citizen.

The law stipulates that the target of handling the poor is addressed to a. Individual; b. family; c. group; and/or d. Community. The handling of the poor is done by using: a. humanity; b. social justice; c. Nondiscrimination; uninformed. welfare; e. solidarity; and f. Empowerment (Republic of Indonesia, 2011). This provision would have been in line with the conception of Social Work. Social work works well for individuals, families, groups, and communities. The focus of social work is people in the environment. Similarly, the principle of POOR PEOPLE handling as mentioned above is in line with the values of social work: Human Rights, Dignity, Diversity, Social Justice (Ashley Miller,2016).

In RI Law No.13 / 2011, stipulated that the handling of poor people is implemented in 7 forms, namely: a. the development of self-potential; b. food and clothing assistance; c. provision of housing services; d. provision of health services; e. provision of educational services; f. provision of access to employment and endeavor; g. legal aid; and/or h. social services (Article 7). Handling of the poor can be done through the following activities: a. empowerment of community institutions; $b$. increasing the capacity of the poor to develop basic skills and business capabilities; c. Guarantee and social protection to provide a sense of security for the poor; $d$. Partnerships and cooperation among stakeholders; and/or e. Coordination between ministries/agencies and local governments.

In Indonesia, as stipulated in the Act, the implementation of poor people handling is carried out by the Minister of Social Affairs. Implementation is done in a planned, directed, measured, and integrated. However, the duties and authorities of the Minister of Social Affairs are specifically restricted in order to meet the need for the development of self-potential, clothing, food, housing, and social services. While the fulfillment of other needs implemented by ministries/agencies concerned in accordance with the duties and functions but still in the coordination of Minister of Social Affairs.

The poor people handling is done by region approach and with regard to local wisdom. The territory is distinguished by its characteristics, into 5 areas, namely: a. Village; b. Urban; c. Coastal and small islands; d. Left / isolated; and/or e. The border between countries. This means that poor people handling are adapted to the characteristics of the region, rather than uninformed. Poor people handling requires facilities and infrastructure. Facilities and infrastructure for the handling of the poor in Indonesia include a. social homes; b. Social rehabilitation centers; c. Education and training centers; d. Social welfare centers; e. halfway house; and f. House of social protection.

In Indonesia, people have a wide opportunity to participate in poor people handling. Such community participation can be undertaken by a. business entity; c. Community organization; c. Individual; d. family; e. group; f. social organization; g. foundation; h. non-governmental organization; i. Professional organizations; and/or j. businessmen.

\section{Social Worker Facilitating the Poor People}

The companion in Indonesian comes from the word "accompany" (KBBI, 2017) which has a close meaning; close (about brotherhood and so on). The word "accompany" is prefixed and the suffix -I too "accompany" means to accompany closely. The word "accompany" is prefixed with "companion" meaning: the accompanist (in the negotiation and so on). Thus the companion is a person who accompanied or accompanied up close. The poor people companion means the person who accompanies (escorted) from near poor people. Social Worker of poor people companion means a social worker who (appointed) to accompany poor people to help overcome the problem. Since the multidimensional crisis of $1997 / 1998$, the term companion has been widely used to designate the person appointed or assigned to assist the program beneficiaries. The goal for the implementation of the program works well. In the context of poor people handling, it is known that KUBE Assistant 
Companions of KUBE are individuals, groups or institutions that have the competence to cooperate with KUBE in developing ideas and actions to achieve the group's goals (Social Department, 2015).

\section{Social Worker}

Social Worker is a practitioner of social work practice. While social work is a profession of help and a science that is very close to the affairs of the poor. Social work even grows into a profession in response to dissatisfaction with the handling of the poor.

The two main social work organizations in the world, the International Federation of Social Workers (IFSW) and the International Association of Social Work (IASSW) formulated that social work is a practice-based profession and academic discipline that promotes social change and development, social cohesion, empowerment and liberation of people. The principles of social justice, human rights (human rights), collective responsibility and respect for diversity are central to social work. The profession of Social Work is supported by social work theories, social sciences, humanities and indigenous knowledge, social work involving people and structures to overcome life challenges and improve welfare. (Social work is a practice-based profession and an academic discipline that promotes social change and development, social cohesion, and the empowerment and liberation of people.) Principles of social justice, human rights, collective responsibility and respect for diversities are central to social work) (Rory Truell, 2014; IFSW, 2014).

The main mission of the Social Worker's profession is to improve human welfare and help meet the basic needs of all people, with particular attention to the needs and empowerment of vulnerable, oppressed and living in poverty. Historically the profession of social work focuses on the well-being of individuals in the social and welfare context of society. This means that in a social worker has been instilled a motivation to perform the task of helping all people improve their welfare, meet basic needs. It is mentioned that social workers pay special attention to the needs and empowerment of vulnerable, oppressed and living in poverty.

The fundamental thing for social work is the attention to the forces of the environment that make, contribute, and solve problems in life. The goal is to promote human and community welfare. The goals of Social Work are actualized through the pursuit of social and economic justice, the prevention of restrictions on human rights, in poverty alleviation and the improvement of the quality of life for all. In carrying out the mission and fulfilling its objectives Social Work holds on science, principles, and values, so it is often said that the social work consists of a set of knowledge, principles and values. Knowledge, principle, and value of social work are guides, tools and directions for social workers in handling problems, including poor people handling.

In realizing its mission Professional Social Workers adhere to a number of values. The main values of social work (Ashley Miller, 2016) are service to humanity, social justice, human dignity and worth, integrity, and competence. With the value of service to humanity, social workers recognize that serving others is more important than self-interest and places the fulfillment of the needs of clients above the fulfillment of their own interests. With social justice, social workers struggle for justice (seeking social change) to defend the interests of marginalized population groups, such as unemployment, poverty, discrimination and other forms of social injustice. With the dignity and worth of dignity, the social worker upholds every human life, regardless of background or belief, respect for personal confidence. The value of integrity (integrity) means that social workers act with honesty, responsibility, and ethics at all times. The social worker is trustworthy and does not betray the client. Whereas, competence (competence), means that social workers continually seek to increase knowledge and to contribute to the profession. 


\section{The Role of Social Workers in Facilitating the Poor Alleviation Program}

Referring to the nature of poor people as a problem person, it is clear that the poor person or family is one of the targets of social work services. Illustrated above that poor people is a living condition in which people are unable to meet their basic needs. While social work missions are clearly stated to improve human well-being and help meet the basic needs of all people, with special attention to the needs and empowerment of vulnerable, oppressed and living in poverty. Therefore, according to the mission of the profession, social workers are very suitable to be a companion for the poor, the poor in particular.

Social Worker The companion of poor people is a person who has the qualification with the minimum education of bachelor of social work or social welfare appointed and or placed with the special task to assist poor people in a certain area. They should (have) certified as special social workers as companions of the poor. Hierarchically functional they are the spearhead of the poor people handling the team from central to regional. Their status is contracted under the Ministry of Social Affairs. Their working area may be a village or sub-district, depending on the number of poor people populations. For the initial phase can be placed at the sub-district level but to focus can be concentrated on some villages or villages considered the most urgent. In carrying out the task of social worker for poor people seconded to the Local Government like Social Service and received supervision from the Head of Social Empowerment. The duty of Social Worker of poor people companion is to assist all poor people in their area. The auxiliary poor people Social Worker is expected to perform the following functions:

Guiding the public to perform poor people data collection so that data is available by name by addressing poor people in the region;

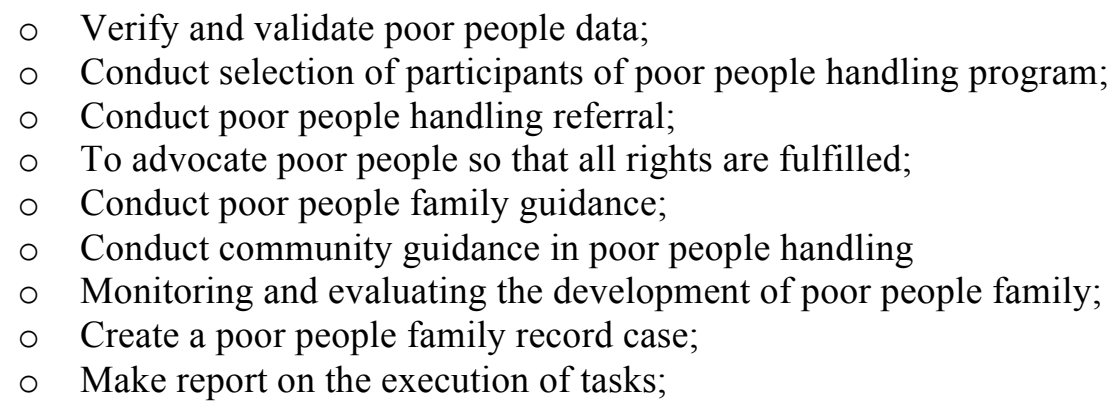

The function of guiding the public is to do poor people data, so that data is available in name and address of poor people in the region. This function is done periodically and continuously so that always available accurate and actual data. This will be very helpful to solve one of the obstacles that have been faced in the implementation of poverty reduction programs in general and social protection programs in particular. Community involvement in poor people data collection is important with the objective: to enable the community to take responsibility in handling poor people; for better data accuracy, optimally reducing exclusion and inclusion error; no poor families feel neglected. Implementation of data collection must be done officially and well coordinated. Official and coordinated in question is where the implementation carried out under the knowledge of the lowest officers and involving local residents. In order to carry out this activity, a standard technical guideline should be developed.

Function to verify and validate poor people data in connection with poor people registration pursuant to Law Number 13/2011. Under Law No.13 / 2011 it is stated that verification and validation as referred to in paragraph (4) shall be implemented by the potential and source of social welfare in sub-district, village or village. Families who meet the criteria as poor people are included in the BDT, processed in accordance with the provisions of the Act. The law states that verification and validation results are reported to the regent/mayor. Then, it is forwarded to the governor to be forwarded to the Minister. The expectation of getting in BDT, poor people family can get their rights, such as social protection programs. In order to carry out this activity, a standard technical guideline should be developed. 
The selection function of the participants of the poor people handling program is intended to determine the participants of the poor people handling the program. Not all poor families already registered in BDT automatically become program participants. Each program has its own target characteristics or criteria, as well as the poor people handling program by Social Department has its own criteria. The poor people companion social worker is given the authority to conduct the selection to be proposed by the regent/mayor to the Minister of Social Affairs to be a participant of the program. In order to carry out this activity, a standard technical guideline should be developed.

The function of referring poor people handling in question is to channel each poor people in order to obtain appropriate services. Every individual and family poor people must be guaranteed their rights, for example, children under five receive services at Local Health Post and other health services, from school age to get education service in school, and poor people children get Smart Indonesia Card, Healthy Indonesia Card and so on. Poor families have access to capital loans and/or other facilities provided by the government. Through this function, it is expected that no one or one poor people family will not get the services it deserves. The Poor People Social Worker Companion is obliged to make referrals. Related to this is necessary synergistic relationship with other institutions. In order to carry out this activity, it is necessary to prepare standard technical guidance received by cross ministry/institution.

The function of advocating poor people so that all rights are fulfilled, no individual or family experiencing exclusion is ignored. In the case of a program not yet in its working area, the social worker may urge the government to include the program in the region. In the case of the village, the social worker may urge the village government to allocate some of the village funds for poor people's benefit. In cases where many children do not have a residence identity (birth certificate), a social worker can insist on cross procurement programs for birth certificates, and so on. In the case of an area found many victims of drug abuse, a social worker can urge the authorities to prevent the circulation of drugs.

The function of conducting poor people family guidance aims to guide families accessing available services; carrying out its responsibilities as mentioned in Law No.13 / 2011; including performing family functions well; guiding families to use money well and productive activities; motivating children to go to school and others.

The function of guiding the community in poor people handling is intended for the community to actively carry out poor people handling with effective and efficient techniques. In every society, there is always a tradition of help. A social worker can motivate and guide people to do more activities to help effectively. Social Workers can also encourage people to adopt more productive habits, such as stay away from gambling. Poor people counselor is also potential to be a source of information. Paying close attention to social supporters in the community such as PKH assistants or other social activists, by many people serving as a reliable source of information. Things are in common, relationships that have awakened in the long run have grown trust. In the community often arise cases of fraud, for example: related to the sending of Indonesian Blue-Collar Workers (TKI) or fake investment. As a result, residents become victims, to suffer. Poor people counselor can be used as a reference for reliable information, preventing citizens from becoming victims of fraud. Even poor people facilitators can function to provide illumination to prevent social conflict, social disintegration and national divide in general.

The function of monitoring and evaluating the development of poor people family is monitoring the development of family condition from time to time, especially after obtaining the services of certain programs, then doing a joint evaluation of the achievement of family progress.

The function of making the poor people family's case record is intended for the development of the family to be well organized, to be evaluated evidence-based. One of the weaknesses of poor people handling so far is the lack of intensive mentoring conducted. Poor people handling through KUBE, more companion attention is devoted to the group, while attention to the family is relatively less. Through Social worker of poor people companion, the focus of attention is more focused on the family. 
Meanwhile, the group is positioned as a mere supporter. This kind of thing is more suited to the social work mission. As outlined in textbooks, the focus of social work attention is on the interests of individual welfare and family functioning. In the case record, social worker notes well the initial conditions, perceived problems and agreements on steps taken by families and social workers. Periodically, Social Workers come to monitor the implementation of the agreement and the results achieved. At the meeting, social worker member notes the progress report and the next agreement. Supervisors who come can learn it.

The function of making a report on the execution of the duties referred to as professional accountability. Through the report, Social Responsibility activities are monitored and controlled by supervisors from the Central, Provincial and City / District. In performing their duties as poor people companion, social workers will understand the poor people problem in the context of the social environment to which it belongs, or the social environment that oversees the poor people concerned.

\section{Companion Work Procedure}

The implementation of poor people assistance by social workers is a professional practice activity. Therefore it is done optimally by deploying all of its professional competence, using professionally responsible techniques (in accordance with principles) and referring to the values of the professional social worker. The purpose of poor people assistance by Social Workers is for problem-solving, which is to help poor people to solve the problem. The objective of the poor people social assistance worker service is to all the poor families in the particular area that they are assigned to. In accordance with the concept of human - in - situations, (Florence Hollis, 1964), the important companion has an understanding of the macro situation that oversees poor people in the local area. Therefore, the work procedure of assistance is initiated by mapping the situation of the region, identification of poor people family (verification and validation of data of poor population/family), and poor people family handling.

\section{The first stage, area mapping}

The area mapping aims to obtain an overview of the general socio-economic situation of the local community, which overshadows the life of the local poor people family. This is seen as important because the handling and understanding of human problems in social work practice are done in the context of local social situations. Individual problems are seen or understood in relation to the social situation that surrounds them. Each social worker assigned to assist in a region is obliged to understand the situation of the local community as a whole. Important social workers have general local area data, ranging from:

1. Population (by gender, education, age, religion);

2. Economics (population livelihoods, commodities produced, marketing networks of products/products and materials / economic inputs (if agriculture means agricultural products and inputs), available economic institutions;

3. Socio-cultural (traditions of both society that support productivity and that hamper productivity, socio-cultural institutions);

4. Existing or ongoing development programs, including social protection programs (PKH, KIS, KIP, Raskin), sector programs (agriculture, fisheries, cooperatives and others); local government programs.

5. Available service institutions (schools, hospitals, social, banks, cooperatives).

All such general data is used by the social worker as a material to understand the local macro-poverty issues. Understanding the macro situation is important because it has links to micro, individual and family issues. This is in accordance with the concept of human - in - situations, which in understanding individual problems are viewed in terms of the circumstances surrounding them.

The second stage, identification of the poor family 
The poor people family identification stage aims to obtain poor people family data (name and address) in its working area. Poor people Social Worker Companion should have poor people family data throughout their territory. To that end, the companion uses the data already available as the initial data, namely Integrated Database (BDT). Poor people companion perform BDT validation and verification. This is in accordance with RI Law Number 13 The year 2011 on poor people handling. The Act states that the verification and validation of poor people data are carried out by the potential and source of social welfare in the sub-district, village or village. Verification and validation results are processed as stipulated in the Act, which is reported to the regent/mayor. Subsequently by the Regent / Mayor forwarded to the Minister for inclusion in the Poor Integrated Database.

\section{The third stage, poor family companion}

Poor Family Companion aims to solve the problems of each poor people family, alleviating poverty. The process of implementing poor people assistance by social workers is conducted professionally through the following steps: 1. Understanding the Problem; 2. Preparation of Problem Solving Plan; 3. Implementation of the Plan; 4. Evaluation of Implementation of the Plan.

\section{Problem Understanding}

Social Workers are obliged to understand the problems of every poor people family who becomes their clients. Understanding the problem is an activity that aims to identify (analyze) the problems faced by the poor people family, as a client. Problem understanding is a skill in itself. In practice, social work must be done by a social worker with the client. The substance is that the problem formulated is a mutual agreement, not like a unilateral understanding by a social worker or by the client. The problem is the gap between the ideal situation and the real situation of need fulfillment. There can be an understanding between social worker and different clients. If there is a difference in understanding it becomes the task of the PS to guide the client to arrive at the same understanding. The same understanding becomes important as it becomes the basis for establishing a problem-solving plan. At this stage in the science of social work is known the concept of real need and felt the need. In an attempt to solve the problem, it is necessary that the real need and felt need are the same. Rationally, the client will be motivated to conduct activities that aim to realize felt the need. In the case of the interests of problem-solving activities required is an activity aimed at realizing the real need. In this case, it is required professional techniques and skills.

\section{Preparation of Problem Solving Plan}

The substance of problem-solving is the realization of self-help (client help) to meet the needs of its members. The problem-solving plan includes the steps agreed upon by the family with the social worker. The family is guided using the potential possessed by increasing productivity, developing a business or finding a job. In this case, social workers can and it is important to link the family with the source system available in the community whether provided by the government or provided by the community. The sources provided by the government include all programs, such as social protection programs (Family Hope Program, Subsidized Rice Program, Subsidized Electricity, Subsidized House, Subsidized Gas, Health Insurance (Healthy Indonesia Card), Educational Cost Assistance (Smart Indonesia Card), and other sources. The task of the social worker is to make every poor people family and each of its members obtains their rights and on the other side carries out their duties.

The right of poor people family in question covers all rights as human beings and citizens, starting from the right to get basic needs, food, education, shelter, health insurance and so on. On the other hand, every poor people family, motivated, guided to perform its duties. All available resources are used to develop the capacity of families to help them, to be constantly on the lookout for outside help to create dependence.

\section{Implementation of the Plan}


Implementation of a problem-solving plan is an effort to carry out a predetermined plan. Given the social unit that the client is a family then each family member has an obligation to engage in implementation. In planning it should have elaborated what the duties of husband/father, wife/mother, and each child, or other people who become members of the household. For example 1. Increased family productivity. The husband performs 1, 2 and 3 duties. The wife performs assignments 1, 2, and 3. The child performs assignments 1,2, and so forth. On the other hand also set control of expenditures (children snack, food procurement, limiting the use of electricity, and others). We recommend that each family is also required to set aside a certain amount of income (a certain amount of rupiah) to save.

\section{Evaluation of Implementation of the Plan}

All family plans that have been set together are regularly monitored and evaluated. Has it been done or not, and how is the result? The results of the evaluation have been successful or have not succeeded, serve as the basis for preparing the next plan.

\section{Case Record}

As a professional practice of poor people companion should be done with professional rules, can be accounted scientifically. Related to the professional responsibility of the poor people companion is obliged to make a case record on each poor people family. Case records are made standardized, containing: a) family identities with all members; b) livelihoods; c) problems encountered; d). potential owned; e) problem-solving plan; periodic progress reports; and f) the next agreement (plan).

- Family identity, including name, age, gender, education, occupation, identity (birth certificate, marriage certificate, ID card)

- The source of income covers all the sources from which the family earns both income and food.

- The potential family includes all resources owned by the family, namely: human resources, material assets, and social capital (owned networks).

- Problems encountered include; a) the needs of each individual member who is not being met well; b) issues related to family livelihoods.

- Troubleshooting plan

\section{Companion Report}

The poor people companion report is standardized contains the progress report of poor people handling in its territory. The report serves as a professional accountability of the task accompaniment implementation. It is important to formulate the components of the report and details the development indicators of each poor people family case, so that information can be displayed in the form of statistics, which are easily seen up and down. Some of the things that are considered important are:

1. Total population (poor people family); can be spelled out in several variations, e.g.: poor people family according to the gender; poor people according to source of livelihood; according to age; and region (city, village, coastal, small islands)

2. Poor people according to program followed (social protection, rehabilitation, and empowerment).

3. Implementation of poor people handling activities or poverty in general in the local area

4. Activities were undertaken and results achieved

5. Statistics progress report of poor people family (client only)

6. Discussion of activities, containing the opinion of the relevant social worker on the progress or obstacles faced in carrying out the mission.

The principle of the counter-report is to inform the implementation of the mentoring activities and the results achieved, as outlined in measurable figures. Supervisors have the obligation to do the filling of the contents of the report and respond. The companion reports should be made quarterly, taking into 
consideration: a) within 3 months of the relatively large number of client and PS activities, the progress of achievement is increasingly visible; b) the companion time is not drained out of report; c) small incidents that need to be submitted to the supervisor can be done in another mechanism without waiting for three months.

Based on the experience of assisting the poor people family, observing the PKH facilitation is estimated that poor people social worker companion effectively mentoring over 300 to 400 families living in a district or village. All families must be accompanied by the ultimate goal of alleviating them from poverty. In order for measurable activities, before the activity is done first agreed on the size.

\section{Opportunity for Social Worker in Poverty Facilitation}

Indonesia Independence aspires to promote the common prosperity and educate the life of the nation. So far the commitment of the Indonesian nation to realize these ideals is still strong. National development policies from time to time consistently reflect this in 2014-2019.

The commitment of the Indonesian nation to advance the general welfare and educate the life of the nation is also supported by the development trend of human civilization. Agreement between nations as reflected through the MDGs in 2000 to 2015 and continued with SDS 2015 to 2030. Indonesia became part of this movement.

Limitations of resources require all activities to be performed more efficiently until required effectiveness of methods/techniques included in poor people handling. In the context of poor people handling, such spirit is reflected in the RPJM 2015-2019. Criticism of the increasing budget allocation and the slow pace of decline in the number of poor people reflect the demands of professionalization.

Competition between nations in the era of globalization is the urge to spur poor people handling. A nation whose people live in poverty faces a threat to its existence. Therefore, for every nation that wants to exist, there is no choice but to tackle the problem of poverty more quickly. Currently, the government and all components of the nation want to increase the effectiveness of handling poverty, including poor people. No other way of improving the effectiveness of poor people handling should be done through professionalization.

Social Worker is a profession born and developed around the world to improve human welfare. Social Workers are consistent with the mission of promoting public welfare, paying particular attention to vulnerable and disadvantaged groups, in harmony with the ideals of the Indonesian nation. Social Workers are equipped with principles of professional practice and guided by humanitarian values, human rights, social justice, diversity, democracy, human dignity, and human service ethics.

Mentoring without professionalization is vulnerable to inefficiency, the crime of humanity. The exploitative relationship in society is an unprofessional portrait of relationships.

The professionalism of poor people family companion will be successful if supported by other policies, include: 1) The implementation of development programs aimed at poverty reduction is carried out more flexibly, in the sense that it is open to all citizens who meet the criteria; 2) All stakeholders have the same passion, serve better.

\section{Conclusion}

What is put forward in this paper, the formation of the Social Worker of the Poor Family Companion, as described above, is an idea. As a result of thought, although compiled on the basis of logic but still untested. Therefore, what if this idea is to be applied first need to be tested in the field? Through the testing process in the field of detail and specific matters can be formulated more applicable. One of the things that should be taken into consideration is the position of poor people social worker companion is in the village, directly do the assistance or at the district level as the coordinator of the companion. In 
the position of Coordinator, Professional Social Worker, acting as an expert, he continued to perform direct service but in carrying out assistant duties, i.e. counselors at the village level, as it is known so far. The village counselor is in charge of daily assistance, as directed by the professional social worker. In such a position, the reach of professional social workers doing services can be broader and more massive.

\section{References}

Badan Penelitian dan Pengembangan Kesehatan, Kementerian Kesehatan RI. (2013). Riset Kesehatan Dasar Tahun 2013. Jakarta: Badan Penelitian dan Pengembangan Kesehatan, Kementerian Kesehatan RI.

Badan Perencana Pembangunan Nasional. (2009). Nota Keuangan Anggaran Pendapatan dan Belanja Negara Tahun 2009 Buku II. Jakarta: Bappenas.

Badan Pusat Statistik. (2017). Jumlah Penduduk Miskin, Persentase Penduduk Miskin dan Garis Kemiskinan, 1970-2015. https://www.bps.go.id/linkTabelStatis/view/id/1494 diakses 12 Juli $\underline{2017}$

International Federation of Social Work. (2014). Definisi global Pekerjaan Sosial. http://ifsw.org/policies/definition-of-social-work/ diakses 1 Juli 2016 pkl 14.52

Lippit, R., Watson, J., Westly, B. (1958). The Dynamics of Planned Change. New York, Harcourt: Brace \& World Inc.: 12.

Miller, A. (2016). Top 5 Values in Being a Social Worker. Demand Media. http://work.chron.com/top-5-values-being-social-worker-11466.html diakses 21 Juli 2016

Kementerian Sosial RI. (2013). Keputusan Menteri Sosial Nomor 146 Tahun 2013 tentang Penetapan Kriteria dan Pendataan Fakir Miskin dan Orang Tidak Mampu. Jakarta: Kementerian Sosial.

Kementerian Sosial RI. (2015). Pedoman Pelaksanaan Kelompok Usaha Bersama (KUBE) Tahun 2015. Jakarta: Kementerian Sosial RI, Direktorat Jenderal Pemberdayaan Sosial dan Penanggulangan Kemiskinan, Direktorat Penanggulangan Kemiskinan Perkotaan.

Republik Indonesia. (2010). Peraturan Presiden RI. Nomor 15 Tahun 2010 tentang Percepatan Penanggulangan Kemiskinan. Jakarta: Republik Indonesia

Republik Indonesia. (2010). Peraturan Presiden RI Nomor 10 Tahun 2010 tentang Percepatan Penanggulangan Kemiskinan.

Republik Indonesia. (2014). Peraturan Presiden RI. Nomor 166 Tahun 2014 tentang Program Percepatan Penanggulangan Kemiskinan.

Republik Indonesia. (1993). Instruksi Presiden RI. Nomor 3 Tahun 1996 tentang Memantapkan Program Menghapus Kemiskinan (MPMK).

Republik Indonesia. (2013). Undang-Undang RI. Nomor 13 Tahun 2011 tentang Penanganan Fakir Miskin.

Rory Truell. (2014). What is social work? https://www.theguardian.com/social-carenetwork/2014/jul/07/what-is-social-work

Rubiyanto, dkk. (2017). Dampak Kelompok Usaha Bersama dalam Penanganan Kemiskinan. Jakarta: Pusat Penelitian dan Pengembangan kesejahteraan Sosial.

Suharto, E. (2016a). Pekerjaan Sosial dan Paradigma Baru Kemiskinan http://www.policy.hu/ suharto/modul_a/makindo_24.htm diakses 16 Juli 2016

Suharto, E. (2016b). Pendekatan Pekerjaan Sosial Dalam Menangani Kemiskinan. http://www.policy .hu/suharto/modul_a/makindo_29.htm diakses 11 Juli 2016

Suharto, E. (2016c). Konsep dan Strategi Pengentasan Kemiskinan Menurut Perspektif Pekerjaan Sosial. http://www.policy. hu/suharto/modul_a/makindo_13.htm diakses 12 Juli 2016

Sitepu, Anwar. (2016). Analisis Efektifitas Kelompok Usaha Bersama (KUBE) Sebagai Instrumen Program Penanganan Fakir Miskin. Majalah Sosio Informa Volume 01 Nomor 01 Tahun 2016. Jakarta: Puslitbang Kesos.

Tangdilinting, P. (1991). Kesejahteraan Sosial Sebagai Suatu Disiplin Ilmu. Media Informatika Penelitian dan Pengembangan Kesejahteraan Sosial Nomor 27, Tahun 1991.

Tim Nasional Percepatan Penanggulangan Kemiskinan. (2016). (http://www. tnp2k.go.id/id/ kebijakan-percepatan/pendahuluan/) diakses 19 Jan 2016) 